\title{
Researches on the capitalization of some medicinal plants to obtain essential oils by using the performant innovative installation EUV 2x1000 type
}

\author{
Ion Grigore ${ }^{1, *}$, Andreea Iulia Grigore ${ }^{1}$, Laurentiu-Constantin Vlăduțoiu ${ }^{1}$, Mario Cristea ${ }^{1}$, \\ Elena Sorica $^{1}$, Dragos Dumitru ${ }^{1}$, Florin Sirbu ${ }^{1}$, Gabriel Badea ${ }^{3}$, Marius Raischi $^{3}$, Denisa \\ Duţă $\breve{4}^{4}$ and Roxana Andreea Sandu $^{5}$ \\ ${ }^{1}$ INMA, TestingDepartment, Ion Ionescu de la Brad Blv. No. 6, Sector 1, Bucharest, Romania \\ ${ }^{2}$ ICDPP Bucharest, Romania \\ ${ }^{3}$ INCDPM Bucharest, Romania \\ ${ }^{4}$ IBA Bucharest, Romania \\ ${ }^{5}$ INCDTP Bucharest, Romania
}

\begin{abstract}
The article includes research on the production of essential oils from medicinal plants by applying water vapour distillation, the method most commonly used for the extraction of essential oils from plants. The results consist of extracting the essential oil from 2 types of medicinal plants: lavender and mint with the help of the EUV installation. The paper highlights the important aspects of obtaining quality products, on economically advantageous terms, addressing both specialists, farmers in larger farms and family associations. The article presents the experimental research results on obtaining essential oils from medicinal plants. Oils obtained by this method contain only volatile components, while wax and volatile resins are not found in the finished product.
\end{abstract}

\section{Introduction}

Medicinal plants are a real source of health. They have healing properties since ancient times and even today they enjoy special attention. Aromatic medicinal plants are found in nature as well as in cultures set up by small producers. Modern medicine recommends them as a natural remedy easy to obtain, cheap, effective and harmless. This is why in our country there is a large campaign for harvesting and capitalizing of medicinal plants, regardless of the season [1,2]. Through the richness of terpenes and phenols, in alcohols and aldehydes, flavoring medicinal plants have demonstrated, over time, therapeutic antiseptic effects, so volatile plant oils administered in useful therapeutic doses have low toxicity, do not produce side effects and do not have contraindications (if administered

*Ion Grigore: ionica grigore2001@yahoo.com 
correctly). From a chemical point of view, volatile oils are complex mixtures of aliphatic and aromatic hydrocarbons, aldehydes, alcohols, esters and other constituents, but predominantly terpenoid compounds. In the past, they were called etheric oils, essential oils or aromatic essences $[3,4,5]$. Essential oils have been used for thousands of years for their healing and purifying effects on the body. They have always held an extreme value for doctors and ancient healers who have used them for aromatherapy, consumption and application on the skin. Research has now revealed its remarkable healing properties $[6,7]$.

Essential oils are concentrated by strong antioxidants. They come from raw plant material such as flowers, leaves, wood, bark, roots, seeds and peels [8, 9, 10]. Although they are called oils, these substances do not contain fatty substances: a drop of essential oil placed on a sheet of paper will not leave any trace, as opposed to a vegetable oil.

From the very wide range of medicinal and aromatic plants, we will focus on two of the most appreciated and used plants in our country, with high essential oil content: lavender (Lavandula angustifolia) (Figure 1) and mint (Mentha piperita) (Figure 2). Lavender is a perennial plant, considered a small bush, because the branches are wooded. It has evergreen leaves, even in winter, usually the leaves being green-silver, but there are also varieties of green or silver leaves. They reach maturity in 2-5 years, and can live without problems for 20-30 years. In our country, the most common kind of lavender is the narrow-leaved, 3-4 $\mathrm{mm}$ wide and $30-40 \mathrm{~mm}$ long, called Lavandula angustifolia. To establish a lavender plantation on a 1 ha area, are needed about 18,000-20,000 seedlings that reach maturity after 3 years and production of green flower (fresh) can reach 4,000-4,500 kg/ ha. If summer harvesting is done properly, you can also perform an autumn harvest from which you could get another 1,500-2,000 $\mathrm{kg}$ of lavender flower. Lavender essential oil is very used in medicine, cosmetics and perfumery.

Between the plants whose chemical composition can generate a significant amount of volatile oils and floral water, lavender occupies a leading position $[1,3,4]$.

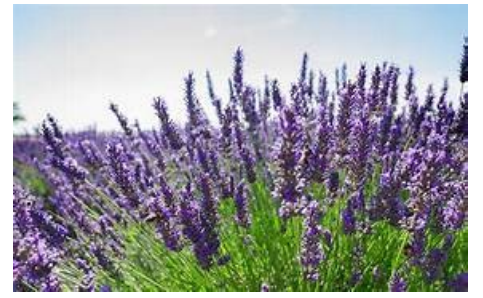

Fig. 1. Lavender (Lavandula angustifolia) [11]

Mint (Mentha piperita) (Figure 2) is one of the oldest known medicinal herbs. "Papyrus Ebers" mentions that mint was used with 1550 years before our time in Egypt. In Europe it was first cultivated in England (1760), where the first quantities of volatile oil were obtained [12]. The largest volatile oil production (3/4 of world production) is provided by the United States. To the world production of volatile oil of mint competes England, France, Italy, Bulgaria, Russia and Japan. Mentha piperita is a sterile hybrid, which in agricultural practice is propagated exclusively by vegetation, using the underground stools. Sometimes, for scientific purposes, mint is propagated by aerial stools, by the rooting of stem or even leaves [13]. Unlike many other plants and essential oils, the benefits of mint oil and mint have been studied and confirmed by the scientific community. Mint oil contains many minerals and nutrients, including iron, manganese, magnesium, calcium, folic acid, potassium and copper. It also contains omega-3 fatty acids, vitamin $\mathrm{A}$ and $\mathrm{C}$. Mint harvesting can be done when the leaves reach 5-6 cm and a 50\% inflorescence, time when the essential oil quantity is optimal. The ideal time for harvesting is in the morning between 10-14 o'clock in sunny weather, without dew, wind or fog [14]. 


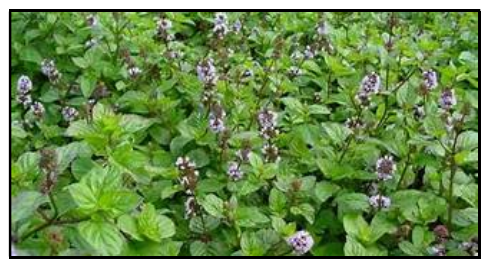

Fig. 2. Mint (Mentha piperita) [15]

Removing a flavor from its natural environment is not an easy operation. It must be isolated or concentrated with a minimum of loss and compositional changes and without introducing new impurities.

Numerous factors can interfere and influence the quality of the distillation and the oils obtained. The operator performing the distillation must documents itself upon:

- the choice of distillation method for the chosen plants;

- the rules to be respected for the distillation of the retained plant;

- the quality of the flower which has effects on efficiency and quality, generally.

If the flower is collected at maturity, then the yield of distillation as well as the quality of the oils will be better. It can be seen an increase in yield and quality of up to $25 \%$.

The time of collection, the quality of the transport materials (aerated bags made of natural materials), the storage time, the time between collection and distillation, the duration of distillation, the distillation temperature, the degree of cleaning of the alembic, the quality of the water required for the steam, the condensation temperature, all influence the yield and quality of the oils obtained.

The user must test the installation with his harvested plants to determine the best distillation parameters.

\section{Materials and Methods}

\section{Technologies for obtaining volatile oils}

The industrial extraction of volatile oils from various aromatic plants is performed according to different methods depending on their characteristic properties.

Each method is important and has its place in the production process of essential oils.

The main methods of obtaining volatile oils are [16]:

- Water vapor distillation;

- Extraction of volatile oils with organic solvents;

- Extraction with animal fats: enfleurage and maceration;

- Extraction with liquefied gases (supercritical CO2);

- Extraction by pressing;

- Adsorption on an adsorbent material.

Water vapor distillation is the most commonly used method for extracting volatile oils from most aromatic plants; it is used for industrial scale extraction, but equally effective can be used at laboratory level.

Using the EUV installation (Figure 3), the steam produced by the steam generator enters the vegetative mass, undergoes distillation, destroys the olefin glands cover, volatilizes the oil and then mixes with it. The mixture of water vapor and oil vapor passes into the refrigerant (condensation vessel), where it turns into a mixture of water and volatile oil. The maximum pressure inside the distillation vessel should not exceed 0.2 bar. A clean steam at a pressure of $0.18-0.20$ bar, maximum, it is used. Distillation is generally ideal when the cooling water temperature is maintained between 24 and $35^{\circ} \mathrm{C}$. This mixture reaches the florentine vessel (separation vessel) where the separation occurs, namely, the volatile oil, being easier, deposit into a film above the floral water. 


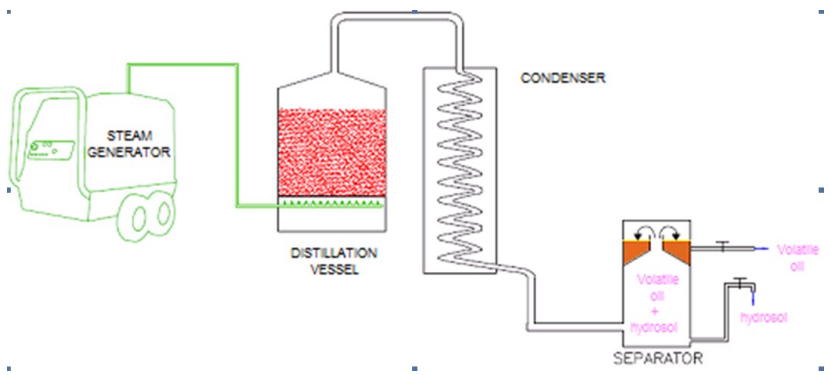

Fig. 3. Technological scheme of EUV distillation equipment

\section{List of components of the EUV installation}

- Stable metal supports for distillation vessels and condenser (cooling vessel);

- Steam generator with pressure regulator;

- One or two 1000 liter distillation vessels equipped with steam inlet/outlet sockets, drain tap and two support sieves for plant;

- Cover for the distillation vessel fitted with: 0.5 bar safety valves and a thermomanometer;

- Condenser (cooling vessel with coil);

- Essences Separator (Florentine vessel);

- Food grade hose - Vaporcord Alim DN or food grade INOX pipe;

- L-type water tap for changing the direction of the flow (EUV-2X1000) (Figure 5).

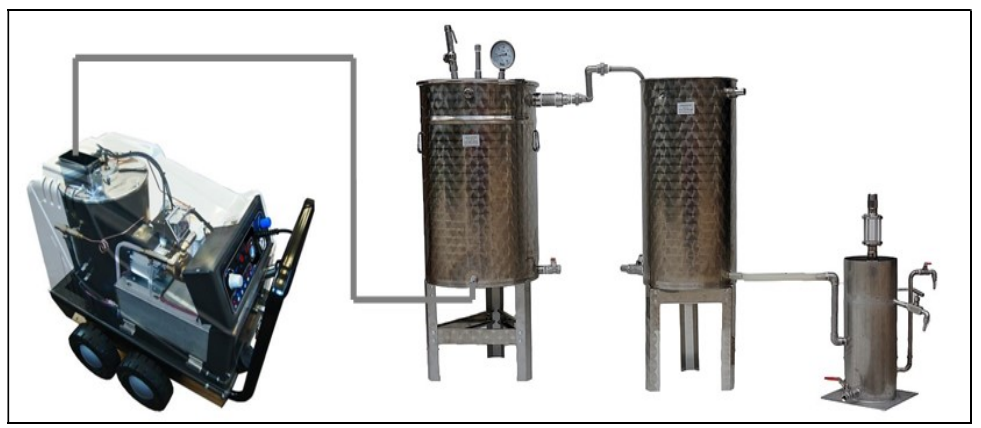

Fig. 4. The water vapor distillation installation EUV-1000

The EUV installation can work with a single distillation vessel fig. 4 or alternatively with two vessels Figure 5. In the case of two distillation vessels, the technical equipment is additionally equipped with two three-way stainless steel L-type water taps, with hoses (stainless steel pipe) for connection to the distillation vessels and the condenser. A water tap shall be installed at the outlet of the pressure regulator fitted on the steam generator so that by changing the outlet path, alternate steam supply through the hoses (stainless steel pipe) of the distillation vessels will be carried out. The second water tap is mounted at the inlet of the cooling vessel and by changing the direction of the flow through the L-type water tap, the alternate passage from one distillation vessel to the other towards the condenser (cooling vessel) is made. All metallic components of the installation are made of food grade INOX. 


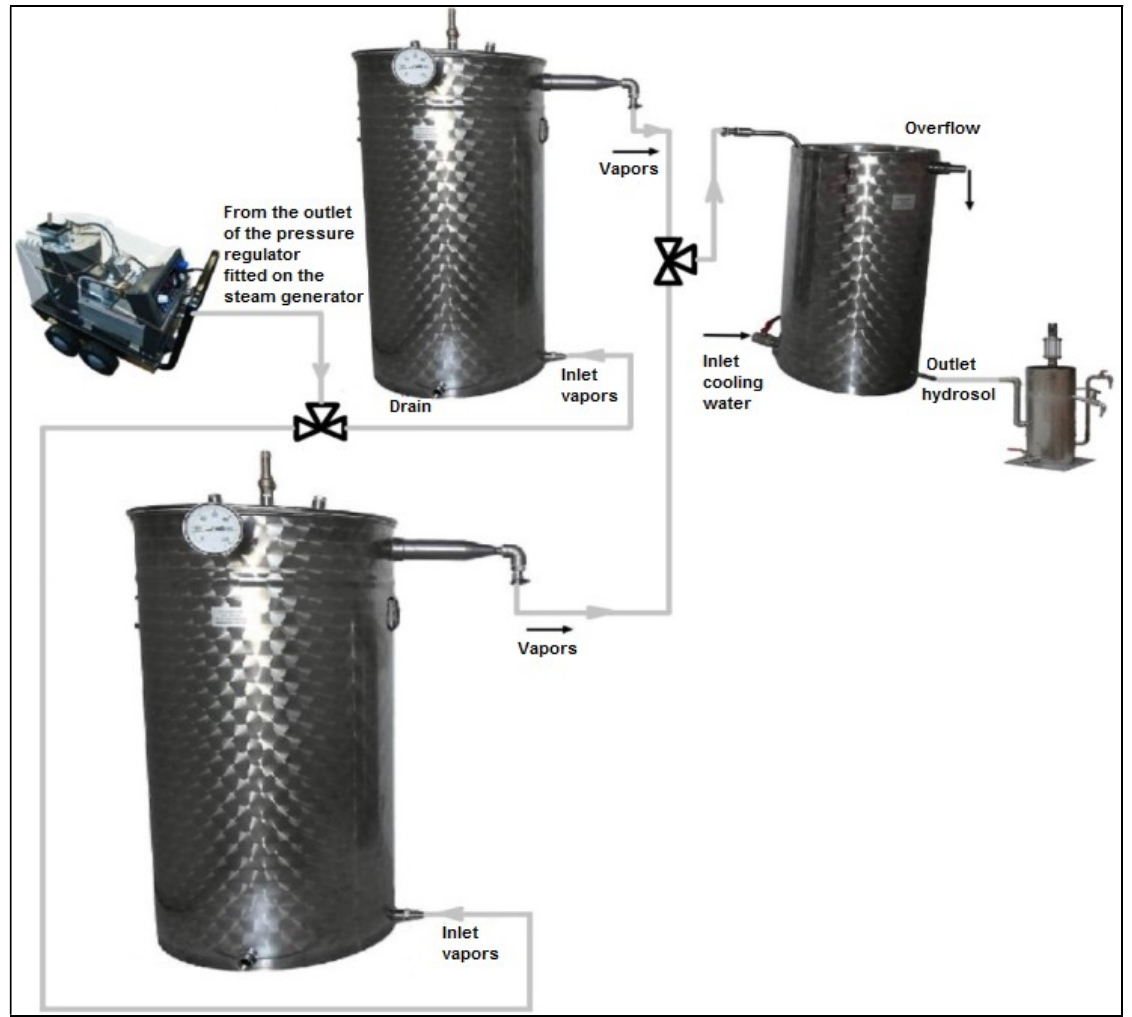

Fig. 5 The water vapor distillation installation EUV-2x1000

\section{Results}

The trials were carried out in Alba county with plants harvested from two lavender plots, respectively mint. Following the trials made, both with freshly harvested plants and dried plants in different amounts, the following results were obtained: with dry lavender, using between $30-90 \mathrm{~kg}$, there were obtained between $0.08-0.271$ of oil (Table 1); lavender freshly harvested, using between $30-120 \mathrm{~kg}$, there were obtained between $0.10-0.451$ of oil (Table 2); dried mint, using between $30-95 \mathrm{~kg}$, there were obtained between $0.12-0.411$ of oil (Table 3) and fresh oil, using between $30-125 \mathrm{~kg}$, there were obtained between 0.17 0.781 of oil (Table 4). The amount of oil that can be obtained from distillation is greatly influenced by the quality of the plants under distillation.

Table 1 Dry lavender

\begin{tabular}{|c|c|c|c|c|c|c|c|c|c|c|}
\hline \multirow{3}{*}{ Raw material } & \multirow{3}{*}{$\begin{array}{l}\text { Quantity } \\
\text { (kg) }\end{array}$} & \multicolumn{6}{|c|}{ Temperatures ${ }^{\circ} \mathrm{C}$} & \multirow{3}{*}{$\begin{array}{l}\text { Time } \\
(\mathrm{min})\end{array}$} & \multirow{3}{*}{$\begin{array}{c}\text { Floral } \\
\text { water } \\
(1)\end{array}$} & \multirow{3}{*}{$\begin{array}{c}\text { Essenti } \\
\text { al oil } \\
\text { (l) }\end{array}$} \\
\hline & & \multirow[b]{2}{*}{ Air } & \multirow{2}{*}{$\begin{array}{l}\text { Cooling } \\
\text { water }\end{array}$} & \multicolumn{2}{|c|}{ Steam } & \multirow{2}{*}{$\begin{array}{c}\text { Interior } \\
\text { vessel }\end{array}$} & \multirow{2}{*}{$\begin{array}{c}\text { Inlet } \\
\text { cooling } \\
\text { vessel }\end{array}$} & & & \\
\hline & & & & $\begin{array}{c}\text { Outlet } \\
\text { generator }\end{array}$ & Inlet vessel & & & & & \\
\hline dry lavender & 30 & 24 & 22 & 124 & 114 & 105 & 89 & 115 & 30 & 0.08 \\
\hline dry lavender & 60 & 24 & 26 & 125 & 114 & 105 & 89 & 115 & 30 & 0.16 \\
\hline dry lavender & 90 & 26 & 23 & 125 & 114 & 104 & 89 & 120 & 30.5 & 0.27 \\
\hline
\end{tabular}


Table 2 Lavender freshly harvested

\begin{tabular}{|c|c|c|c|c|c|c|c|c|c|c|}
\hline \multirow{3}{*}{ Raw material } & \multirow{3}{*}{$\begin{array}{c}\text { Quantity } \\
(\mathrm{kg})\end{array}$} & \multicolumn{6}{|c|}{ Temperaturi ${ }^{\circ} \mathrm{C}$} & \multirow{3}{*}{$\begin{array}{l}\text { Time } \\
(\mathrm{min})\end{array}$} & \multirow{3}{*}{$\begin{array}{c}\text { Floral } \\
\text { water } \\
\text { (1) }\end{array}$} & \multirow{3}{*}{$\begin{array}{l}\text { Essenti } \\
\text { al oil } \\
\text { (l) }\end{array}$} \\
\hline & & \multirow[b]{2}{*}{ Air } & \multirow{2}{*}{$\begin{array}{c}\text { Cooling } \\
\text { water }\end{array}$} & \multicolumn{2}{|c|}{ Steam } & \multirow{2}{*}{$\begin{array}{c}\text { Interior } \\
\text { vessel }\end{array}$} & \multirow{2}{*}{$\begin{array}{c}\text { Inlet vas } \\
\text { cooling } \\
\text { vessel }\end{array}$} & & & \\
\hline & & & & $\begin{array}{c}\text { Outlet } \\
\text { generator }\end{array}$ & $\begin{array}{l}\text { Inlet } \\
\text { vessel }\end{array}$ & & & & & \\
\hline $\begin{array}{l}\text { lavender freshly } \\
\text { harvested }\end{array}$ & 30 & 18 & 18 & 125 & 114 & 105 & 89 & 115 & 30 & 0.10 \\
\hline $\begin{array}{l}\text { lavender freshly } \\
\text { harvested }\end{array}$ & 60 & 20 & 24 & 125 & 114 & 104 & 89 & 120 & 30.5 & 0.21 \\
\hline $\begin{array}{l}\text { lavender freshly } \\
\text { harvested }\end{array}$ & 90 & 23 & 25 & 125 & 114 & 104 & 88 & 120 & 30.5 & 0.33 \\
\hline $\begin{array}{l}\text { lavender freshly } \\
\text { harvested }\end{array}$ & 120 & 28 & 26 & 125 & 114 & 104 & 87.5 & 120 & 31 & 0.45 \\
\hline
\end{tabular}

Table 3 Dry mint

\begin{tabular}{|c|c|c|c|c|c|c|c|c|c|c|}
\hline \multirow{3}{*}{ Raw material } & \multirow{3}{*}{$\begin{array}{c}\text { Quantity } \\
\text { (kg) }\end{array}$} & \multicolumn{6}{|c|}{ Temperaturi ${ }^{\circ} \mathrm{C}$} & \multirow{3}{*}{$\begin{array}{l}\text { Time } \\
(\mathrm{min})\end{array}$} & \multirow{3}{*}{$\begin{array}{c}\text { Floral } \\
\text { water } \\
\text { (1) }\end{array}$} & \multirow{3}{*}{$\begin{array}{c}\text { Essenti } \\
\text { al oil } \\
(1)\end{array}$} \\
\hline & & \multirow[b]{2}{*}{ Air } & \multirow{2}{*}{$\begin{array}{l}\text { Cooling } \\
\text { water }\end{array}$} & \multicolumn{2}{|c|}{ Steam } & \multirow{2}{*}{$\begin{array}{c}\text { Interior } \\
\text { vessel }\end{array}$} & \multirow{2}{*}{$\begin{array}{c}\text { Inlet vas } \\
\text { cooling } \\
\text { vessel }\end{array}$} & & & \\
\hline & & & & $\begin{array}{c}\text { Outlet } \\
\text { generator }\end{array}$ & $\begin{array}{c}\text { Inlet } \\
\text { vessel }\end{array}$ & & & & & \\
\hline dry mint & 30 & 19 & 19 & 125 & 114 & 105 & 89 & 120 & 30.5 & 0.12 \\
\hline dry mint & 65 & 23 & 20 & 125 & 114 & 105 & 89 & 115 & 30.5 & 0.25 \\
\hline dry mint & 95 & 26 & 24 & 125 & 114 & 104 & 88 & 120 & 31 & 0.41 \\
\hline
\end{tabular}

Table 4 Mint freshly harvested

\begin{tabular}{|c|c|c|c|c|c|c|c|c|c|c|}
\hline \multirow{3}{*}{ Raw material } & \multirow{3}{*}{$\begin{array}{c}\text { Quantity } \\
\text { (kg) }\end{array}$} & \multicolumn{6}{|c|}{ Temperaturi ${ }^{\circ} \mathrm{C}$} & \multirow{3}{*}{$\begin{array}{l}\text { Time } \\
(\mathrm{min})\end{array}$} & \multirow{3}{*}{$\begin{array}{c}\text { Floral } \\
\text { water } \\
\text { (1) }\end{array}$} & \multirow{3}{*}{$\begin{array}{l}\text { Essent } \\
\text { al oil } \\
\text { (1) }\end{array}$} \\
\hline & & \multirow[b]{2}{*}{ Air } & \multirow{2}{*}{$\begin{array}{c}\text { Cooling } \\
\text { water }\end{array}$} & \multicolumn{2}{|c|}{ Steam } & \multirow{2}{*}{$\begin{array}{c}\text { Interior } \\
\text { vessel }\end{array}$} & \multirow{2}{*}{$\begin{array}{c}\text { Inlet vas } \\
\text { cooling } \\
\text { vessel }\end{array}$} & & & \\
\hline & & & & $\begin{array}{c}\text { Outlet } \\
\text { generator }\end{array}$ & $\begin{array}{c}\text { Inlet } \\
\text { vessel }\end{array}$ & & & & & \\
\hline $\begin{array}{c}\text { mint freshly } \\
\text { harvested }\end{array}$ & 30 & 21 & 24 & 125 & 114 & 105 & 89 & 115 & 30 & 0.17 \\
\hline $\begin{array}{c}\text { mint freshly } \\
\text { harvested }\end{array}$ & 65 & 25 & 24 & 125 & 114 & 104 & 88 & 120 & 30.5 & 0.37 \\
\hline $\begin{array}{c}\text { mint freshly } \\
\text { harvested }\end{array}$ & 95 & 25 & 25 & 125 & 114 & 104 & 87.5 & 120 & 31 & 0.56 \\
\hline $\begin{array}{c}\text { mint freshly } \\
\text { harvested }\end{array}$ & 125 & 26 & 23 & 125 & 114 & 104 & 87.5 & 125 & 31.5 & 0.78 \\
\hline
\end{tabular}

The productivity differences recorded for lavender and mint, as a result of the use of both dry material and fresh material, are shown in Figures 6 and 7.

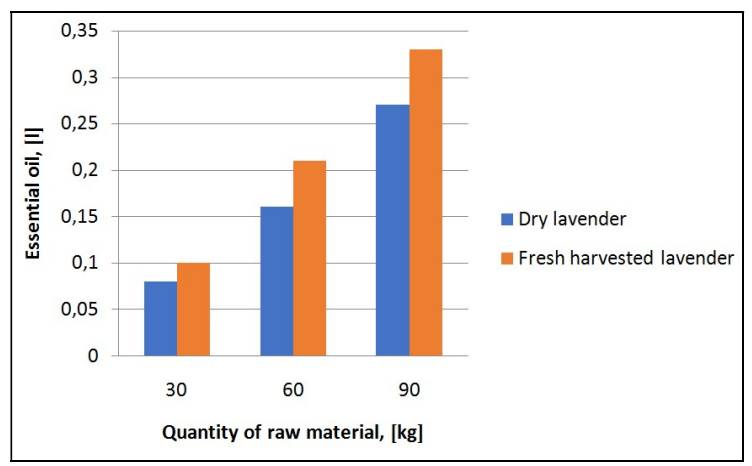

Fig. 6 The productivity of distillation process for lavender 


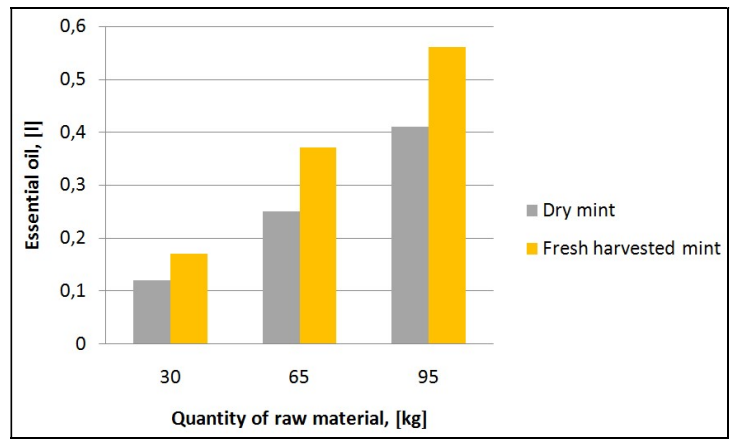

Fig. 7 The productivity of distillation process for mint

In order to prove the effectiveness of the installation with alternative operation EUV2X1000 in comparision with EUV-1000 installation, tests were performed for two days, 10 hours a day, with each variant of the installation. The amount of distillation material was set at $120 \mathrm{~kg}$ freshly harvested lavender for each sample. Thus on the first day tests were made with EUV-1000. The duration of a sample was about 145-150 min, of which 25-30 min represents the times for cooling, evacuation of the meterial, cleaning the vessel and refilling it with the raw material for the next sample. Under these conditions, 4 samples were obtained within 10 hours. The next day with the EUV-2X1000 installation, 5 samples were made with the same amounts of material / sample. All tests were performed at an inlet pressure of 0.2 bar in the distillation vessel.

\section{Conclusions}

After the tests, the following aspects were identified:

- the amount of oil obtained depends largely on the quality of the plants subjected to distillation;

- the distillation time is approximately equal, irrespective of the quantity of plants in the vessel;

- from the freshly harvested plants subjected to distillation, about $25-30 \%$ more essential oil is obtained compared to the quantity obtained from dried plants;

- by using the EUV-2X1000 installation, a larger quantity of plants with about $20 \%$ / day can be distilled, comparing with the EUV-1000, due to the elimination of the distillation vessel refueling times, this being done during the time in which the material from the first vessel is distilled, the distillation stream being continuous.

\section{Acknowledgement}

This work was supported by a grant of the Romanian Research and Innovation Ministry, through Programme 1 - Development of the national research-development system, subprogramme 1.2 - Institutional performance - Projects for financing excellence in RDI, contract no. 16PFE.

\section{References}

1. C. Popescu, A. Pruteanu, D. Cujbescu, I. Grigore, M. Matache, I. Voicea, V. Vlăduţ, E. Marin, C. Popescu, Physical-chemical and microbiological characterization of lavender water obtained as secondary product from lavender (lavandula angustifolia L) essential oil, International Symposium ISB-INMA TEH' 2015 Agricultural and Mechanical Engineering, 30 - 31 October, Bucharest, ISSN 2344-4118, Pages 335-342, (2015); 
2. http://interferente.ro/plante-medicinale-izvor-de-sanatate.html;

3. C. Popescu, I. Voicea, V. Vlăduţ, D. Cujbescu, S. Bungescu, Physical and chemical characterization of the lavender water resulted as waste at the obtaining of the lavender volatile oil, by driving with water vapour (Part 1), Fifth International Conference "Research People and Actual Tasks on Multidisciplinary Sciences", Section 2 - Social and human sciences. Economic sciences. Ecology and Environment protection, Land \& Water Use and Environment, Physics, Chemistry, Biology, Lozenec, Bulgaria, 24 - 28 June, Pages 153-160, (2015);

4. C. Popescu, I. Voicea, V. Vlăduţ, D. Cujbescu, I. Găgeanu, M. Duțu, Physical-chemical characterization of lavender water resulted as waste when obtaining volatile oil from lavender, by engaging with water vapors (Part 2),Fifth International Conference " Research People and Actual Tasks on Multidisciplinary Sciences", Section 2 - Social and human sciences. Economic sciences. Ecology and Environment protection, Land \& Water Use and Environment, Physics, Chemistry, Biology, Lozenec, Bulgaria, 24 - 28 June, Pages 161-168, (2015);

5. http://www.creeaza.com/familie/medicina/ULEIURILE-VOLATILE-ESENTIALE127.php;

6. C. Popescu (Popiniuc), C. Popescu, St. Manea, V. Vlăduţ, I. Voicea, C. Covaliu, H. Abbas, A. Dune, D. Lupuleasa, The influence of extraction solvent on the active principles content of Portulaca Oleracea native species, Revista de Chimie, Volume 69 (10)/2018, Pages 2682-2692, (2018);

7. C. Popescu (Popiniuc), C. Popescu, St. Manea, V. Vlăduţ, I. Caba, C. Covaliu, H. Abbas, A. Dune, D. Lupuleasa, Study on Portulaca Oleracea native species as vegetal source of Omega-3 and Omega-6 fatty acids, Revista de Chimie, Volume 69 (11)/2018, Pages 2973-2980, (2018);

8. C. Popescu, I. Voicea, V. Vlăduţ, Influence of breakage process on increasing the extraction yield of medicinal plants bioactive substances, Romanian Biotechnological Letters, Volume 20, Issue 4, Pages 10561-10571, (2015);

9. A. Pruteanu, C. Popescu, V. Vlăduţ, I. Găgeanu, Biochemical analysis of some vegetal extracts obtained from indigenous spontaneous species of (Thymus serpyllum L.), Romanian Biotechnological Letters, Volume 23, Issue 5, Pages 14013-14024, (2018);

10. https://viataverdeviu.ro/proprietatile-vindecatoare-ale-uleiurilor-esentiale/;

11. https://tse3.mm.bing.net/th?id=OIP.1B6JAuMdraQ1LEk8TSL5yAHaEs\&pid $=15.1 \& \mathrm{P}=0 \& \mathrm{w}=28$ $5 \& \mathrm{~h}=181 \backslash$

12. Solacolu T, Kollo C, Revista sanitara militara, (No 8, 1938);

13. http://plantemedicinale.crestere-melci menta-cultivarea-prelucrarea-si-utilizarea-mentei.ro/27/;

14. https://dietamediteraneana.wordpress.com/tag/recoltarea-mentei/;

15. https://tse4.mm.bing.net/th?id=OIP.siBwpUFwAVvozT51WSObAHaD2\&pid $=15.1 \& \mathrm{P}=0 \& \mathrm{w}=326 \& \mathrm{~h}=171$;

16. http://agro.afacereamea.ro/wp-content/uploads/floricultura/Metode-de-Obtinere-Si-dePrelucrare-a-Uleiurilor-Volatile.p. 